\title{
ARTICLE \\ Construction Technology and Quality Control of Double Layer Con- tinuous Paving of Cement Stabilized Macadam Base
}

Jin $\mathrm{Ma}^{*}$

Wuzhong municipal construction management center Wuzhong, Ningxia, 751100, China

\begin{tabular}{ll}
\hline ARTICLE INFO & ABSTRACT \\
\cline { 3 - 3 } $\begin{array}{l}\text { Article history } \\
\text { Received: } 12 \text { July } 2020\end{array}$ & $\begin{array}{l}\text { The construction method of continuous paving of the upper and lower base } \\
\text { of the water stable macadam base can improve the construction efficiency, } \\
\text { overcome the quality problems of the traditional layered paving of the } \\
\text { upper and lower base, such as untimely curing, slow construction, poor } \\
\text { Accepted: } 12 \text { July } 2020\end{array}$ \\
Published Online: 30 September 2020 & $\begin{array}{l}\text { struction quality of the water stable macadam. It is also the promotion and } \\
\text { application of new technology. }\end{array}$
\end{tabular}

Highway and municipal engineering

Water stable double layer continuous paving

Construction technology

Quality control

\section{Introduction}

$\mathrm{D}$ ouble layer continuous paving of cement stabilized macadam base is a new type of paving method. Under the condition of strict control of mixture and arrangement of construction organization, it is feasible to continuously pave the upper and lower base. On the premise of ensuring the quality, it not only speeds up the construction progress, but also improves the economic benefits.

\section{Mixing of Mixture}

The mixture shall be mixed in the mixing station. Before mixing the mixture formally, the cement stabilized soil mixer must be debugged to make the particle composition and moisture content of the mixture meet the specified requirements. The bin of the mixer shall be labeled and numbered, and different aggregates shall correspond to the corresponding silo. Before loading, the aggregate in the bin shall be mixed to ensure the uniformity of aggregate. The test personnel must stay at the mixing station and calibrate the cement consumption regularly, that is, carry out the cement titration test and establish the account to control the cement consumption. The moisture content of the mixture shall be detected every 2 hours, and the moisture content shall be detected once an hour when the temperature is high, and timely adjust according to the test data ${ }^{[1]}$.

\section{Mixture Transportation}

The mixture is transported to the site by dump truck from the mixing plant. In order to prevent the mixture from segregation, the front part shall be loaded first, then the rear part, and finally the middle part; in order to prevent moisture loss, tarpaulin must be covered during the trans-

*Corresponding Author:

Jin Ma,

Wuzhong municipal construction management center Wuzhong, Ningxia, 751100, China;

Email:2562275375@qq.com 
portation process, and the covering shall be "no outcrop at the front and no leakage at the rear". After the transport vehicles arrive at the site, it is strictly forbidden to uncover the tarpaulin in advance, that is to say, the whole process of the tarpaulin covering should be from loading and leaving the station, transportation to the end of paving. After arriving at the paving site, the transport vehicles should turn around at the opening. It is strictly forbidden to turn around on the paved water stable base to avoid the damage of the lower bearing layer. A special person shall be assigned to direct the dump truck to unload materials. The dump truck shall not impact the paver. When the distance between the dump truck and the paver is $10-30 \mathrm{~cm}$, the dump truck shall stop and shift to the neutral gear to let the paver take the initiative to meet the dump truck. The dump truck shall be pushed forward by the paver ${ }^{[2]}$.

\section{Formwork Support}

The national standard channel steel (size: length $\times$ width $\times$ height $=600 \mathrm{~cm} \times 7 \mathrm{~cm} \times 18 \mathrm{~cm}$ ) with the same thickness as the base course is used as the side formwork at the middle line of the lower base course, and the channel steel is reinforced and supported: one triangular support is set per meter, and the steel drill rod (diameter: $25 \mathrm{~mm}$ ) is used to fix the channel steel end. The joint of channel steel end is supported by inclined ground anchor, and each adjacent joint is welded with a sleeve. After alignment, the end reinforcement of inclined ground anchor is embedded After entering, the formwork shall be inlaid tightly to ensure that the formwork joint is flat, the position is stable, and the alignment is straight and smooth, so as to avoid the influence on the longitudinal joint caused by the edge rolling due to the instability of channel steel, and special personnel shall be arranged to check the stability of the support steel drill rod. Considering the longitudinal joints, the channel steel in the middle of the lower base course shall be offset by $25 \mathrm{~cm}$ from the middle pile position for fixing, so that the upper and lower base layers form a step shape. Shoulder soil is used as retaining structure at the edge ${ }^{[3]}$.

The national standard channel steel (size: length $\times$ width $\times$ height $=600 \mathrm{~cm} \times 7 \mathrm{~cm} \times 18 \mathrm{~cm}$ ) with the same thickness as the base course is used as the side formwork at the middle line of the upper base course, and the channel steel is reinforced with the same support method as the lower base course. Considering the longitudinal joints, the inner side of the channel steel is fixed along the middle pile position during the installation of the middle channel steel of the upper base course, that is, the lower base course is $25 \mathrm{~cm}$ wider than the upper base course, forming a step shape.
The edge of the upper base course adopts the square timber with the same thickness as the base course (size: length $\times$ width $\times$ height $=300 \mathrm{~cm} \times 20 \mathrm{~cm} \times 18 \mathrm{~cm}$ ) as the side formwork, and strengthen the support for the square timber: each two square timber is fixed with a steel drill rod (diameter of $25 \mathrm{~mm}$ ) at $40 \mathrm{~cm}$ from the joint position to ensure that the square wood joint is flat, the position is stable, and the alignment is straight and smooth, so as to avoid the side rolling compaction caused by the channel steel instability and affect the longitudinal joint Arrange special personnel to check the stability of supporting steel drill rod. In consideration of the shift of square timber and formwork during the rolling process of the roller, and the convenience and reduction of workload in the later construction and installation of curbstone, the distance between the inner side of square timber and the inner side of channel steel is determined as $5.15 \mathrm{M}$. After rolling, the width of upper base is $5.2 \mathrm{~m}$, which achieves the expected effect.

\section{Spreading of Mixture}

\subsection{Determine the Appropriate Paving Section}

According to the mixing, transportation, paving and rolling time of mixture (the length of each rolling area is about $50 \mathrm{~m}$, the paving time of each section is about 30 minutes, the rolling time of each section is about $30 \mathrm{~min}-$ utes, and the paving and rolling time of $100-200 \mathrm{~m}$ water stable mixture is about $120-180$ minutes), and the initial setting time of cement in the mixture is 3-4 hours, the final determination is that the lower base course is paved after 100-200m, When the upper base has enough working surface, the upper base course shall be paved ${ }^{[4]}$.

\subsection{Paving Control Points}

Before the paver runs, the elevation and cross slope of the screed shall be adjusted, and the sensor shall be placed on the fixed wire line. Then, the paver's feeding bearing shall be fully rotated to feed, and the screed shall walk when the blanking is fully saturated. Note that after the hopper of the paver is close to the chute of the unloading truck, command the dump truck to lift the truck and lift the chute for unloading. Do not lift it all at once, but gradually lift it with the paver moving forward to prevent the lifting too fast.

Special personnel shall be assigned to monitor the sensors on both sides of the paver to prevent the sensor from breaking away from the reference line during the operation of the paver, which may lead to the control failure of the paving thickness, flatness, cross slope and other indi- 
cators. Secondly, the computer indicator light of the paver shall be controlled so as not to make the sensor and other paving performance lose their functions. If problems are found, timely report and stop the machine for inspection immediately, so as to avoid damage to the paving quality of the base course.

In order to prevent the mixture from falling to the ground from both sides of the hopper of the paver and entering into the paver track, thus affecting the construction smoothness, special personnel must be arranged on site to remove the dropped mixture in time to prevent it from entering under the paver track.

During the paving process, a special person shall be assigned to monitor the paving thickness and cross slope at any time, and two persons shall be set behind the paver to deal with segregation and pits, so as to eliminate the segregation of coarse and fine aggregate and local unevenness in time. During the layered construction of cement stabilized macadam base, when paving the upper base course, the lower base course shall be spread with cement paste

\section{Epilogue}

Due to the cement and other cementing materials contained in the water stability, the whole construction process should be completed before the final setting of cement, and the quality standard should be met at one time, otherwise it is not easy to repair. Therefore, it is necessary to determine the length of the construction section, speed up the construction progress, and select the appropriate construction machinery to ensure that the upper and lower layers form a whole. The construction method of double layer continuous paving is also in line with the development direction of modern large-scale mechanization. Therefore, the application of double layer continuous paving in pavement engineering should be popularized and developed.

\section{References}

[1] Technical rules for construction of highway pavement base (JTG / T f20-2015).

[2] Specification for field test of highway subgrade and pavement JTG e60-2008.

[3] Changsheng He. Construction and Research on ecological development mode of open pit mine in Plateau[J]. Mining research and development, 2019, 39(07): 142-145.

[4] Shibo Sheng. Prospect of ecological construction of green mines in China[J]. Open pit mining technology, 2019, 34(03): 8-10.

[5] Xiaoming Wei, Lijie Guo, Xinzheng Chen, et al. Experimental study on cemented tailings filling in jinchanghe Polymetallic Mine[J]. Mining research and development, 2020, 40(06): 42-46. 